\title{
Pretreatment of Real Wastewater from the Chocolate Manufacturing Industry through an Integrated Process of Electrocoagulation and Sand Filtration
}

\author{
Marco A. García-Morales $\mathbb{D}^{1}{ }^{1}$ Julio César González Juárez, ${ }^{1}$ Sonia Martínez-Gallegos, ${ }^{1}$ \\ Gabriela Roa-Morales, ${ }^{2}$ Ever Peralta, ${ }^{3}$ Eduardo Martin del Campo López, ${ }^{2}$ \\ Carlos Barrera-Díaz, ${ }^{2}$ Verónica Martínez Miranda, ${ }^{2}$ and Teresa Torres Blancas ${ }^{4}$ \\ ${ }^{1}$ Instituto Nacional de México, Instituto Tecnológico de Toluca, Av. Tecnológico s/n, Col. Agrícola Buenavista, 52149 Toluca, \\ MEX, Mexico \\ ${ }^{2}$ Facultad de Química, Paseo Colón s/n, Residencial Colón, Universidad Autónoma del Estado de Mexico (UAEMéx), \\ 50120 Toluca de Lerdo, MEX, Mexico \\ ${ }^{3}$ Universidad del Mar, Campus Puerto Angel, Ciudad Universitaria s/n, 70902 Puerto Angel, OAX, Mexico \\ ${ }^{4}$ Instituto de Química, Carretera Toluca-Atlacomulco Km 14.5, Universidad Nacional Autónoma de México and Centro Conjunto de \\ Investigación en Química Sustentable UAEM-UNAM, 50200 Toluca, MEX, Mexico
}

Correspondence should be addressed to Marco A. García-Morales; magm0904@hotmail.com

Received 20 June 2017; Revised 20 December 2017; Accepted 7 March 2018; Published 3 April 2018

Academic Editor: Mark van Der Auweraer

Copyright (c) 2018 Marco A. García-Morales et al. This is an open access article distributed under the Creative Commons Attribution License, which permits unrestricted use, distribution, and reproduction in any medium, provided the original work is properly cited.

\begin{abstract}
The purpose of this study was to evaluate the efficiency of removal of suspended solids in terms of turbidity, color, and chemical oxygen demand (COD) when integrating the electrocoagulation process using aluminum sacrificial anodes and the sand filtration process as a pretreatment of wastewater from the chocolate manufacturing plant in Toluca, México. Wastewater from the chocolate manufacturing industry used in this study is classified as nontoxic, but is characterized as having a high content of color $(5952 \pm 76 \mathrm{Pt}-\mathrm{Co})$, turbidity $(1648 \pm 49 \mathrm{FAU})$, and COD $(3608 \pm 250 \mathrm{mg} / \mathrm{L})$. Therefore, enhanced performance could be achieved by combining pretreatment techniques to increase the efficiencies of the physical, chemical, and biological treatments. In the integrated process, there was a turbidity reduction of $96.1 \pm 0.2 \%$ and an increase in dissolved oxygen from $3.8 \pm 0.05 \mathrm{mg} /$ $\mathrm{L}$ (inlet sand filtration) to $6.05 \pm 0.03 \mathrm{mg} / \mathrm{L}$ (outlet sand filtration) after $120 \mathrm{~min}$ of treatment. These results indicate good water quality necessary for all forms of elemental life. Color and COD removals were $98.2 \pm 0.2 \%$ and $39.02 \pm 2.2 \%$, respectively, during the electrocoagulation process $\left(0.2915 \mathrm{~mA} / \mathrm{cm}^{2}\right.$ current density and $120 \mathrm{~min}$ of treatment). The proposed integrated process could be an attractive alternative of pretreatment of real wastewater to increase water quality of conventional treatments.
\end{abstract}

\section{Introduction}

Chocolate has a uniquely attractive taste and might even be beneficial for health. The popularity of this food appears to be mainly due to its potential to arouse sensory pleasure and positive emotions. Chocolates are complex multiphase systems of particulate (sugar, cocoa, and certain milk components) and continuous phases (cocoa butter, milk fat, and emulsifiers) [1]. The industrial chocolate manufacturing process consists of the following steps: cocoa collection, cleaning, fermentation, drying, roasting, grinding, pressing, spraying, and mixing, during which a large amount of water is used [2]. The wastewater in the chocolate manufacturing industry contains no hazardous ingredients, but it has a high content of color, total solids (TS), biochemical oxygen demand (BOD), and chemical oxygen demand (COD) [3].

The selection of treatment method is mainly based on the composition of the wastewater. Various treatment methods like (a) biological process, namely, anaerobic and aerobic; (b) physicochemical treatment, namely, adsorption, 
membrane process, reverse osmosis, and coagulation/flocculation; and (c) oxidation processes, namely, ozone and Fenton, have been used for the treatment of industrial wastewater [4]. The aerobic process involves the use of free or dissolved oxygen by microorganisms (aerobes) in the conversion of organic wastes to biomass and $\mathrm{CO}_{2}$. In the anaerobic process, complex organic wastes are degraded into methane, $\mathrm{CO}_{2}$, and $\mathrm{H}_{2} \mathrm{O}$ through three basic steps (hydrolysis and acidogenesis including acetogenesis and methanogenesis) in the absence of oxygen [5]. Although the biological method is widely applied for the treatment of wastewater, too many disadvantages tend to focus on other technologies: the need for longer aeration times, requirement of large land areas, high energy demand, excess sludge production, and microbial inhibition due biomass poisoning [6]. The physicochemical treatment processes are effective for the treatment of industrial wastewater and are quick and compact but are not generally employed due to the associated high chemical and operational costs as well as complex sludge generation [7, 8]. Oxidation processes generate and use mainly hydroxyl radicals to oxidize the organic compounds. $\mathrm{HO} \bullet$ has a high oxidation or standard reduction potential $(2.8 \mathrm{~V})$ [9]. The main characteristics of $\mathrm{HO} \bullet$ are as follows: it is short-lived, it is simply produced, it is a powerful oxidant, it has an electrophilic behavior, it is ubiquitous in nature, it is highly reactive, and it is practically nonselective. It reacts with a wide variety of organic compound classes, producing shorter and simpler organic compounds, or in case of full mineralization [10]. Nevertheless, some researchers have reported that these processes were highly not effective for industrial application [11]. Decolorization through chemical treatment with ozone, Fenton's reagent, and $\mathrm{H}_{2} \mathrm{O}_{2} / \mathrm{UV}$ leads to color reduction due to breaking of the conjugation and or bonds in chromophoric groups. In addition, the formation of potentially toxic oxidation intermediates may occur; therefore, these are not preferred solutions [4].

Due to the complexity of chocolate manufacturing plant wastewater, in which pollutants may be suspended, emulsified, or dissolved, electrocoagulation (EC) represents an interesting alternative for water remediation, providing comparable results with even some advanced oxidation processes in the removal of persistent compounds from pharmaceutical and food industrial effluents $[12,13]$. Among the advantages of an EC process, the following can be highlighted: nonspecificity, similar treatment for drinking water and wastewater, low dosage of chemical reagents, low operating costs, low sludge production (compared to traditional chemical coagulation), absence of moving parts in the reaction setup, and low power consumption if solar energy is used [14]. From a practical point of view, EC must be considered a parallel mechanism that includes charge neutralization and adsorption. At the beginning of the process, realized ions destabilize the system forming metal hydroxide complexes that aggregate suspended particles (flocs) and adsorb dissolved particles $[15,16]$. In addition to the above, at the cathode, gas formation takes place allowing floc floatation. The electrical corrosion of metal in the sacrificial electrode and the formation of hydroxyl anion are the essential reactions in any EC process [17]. The floc formation is a complex process; according to the Derjaguin-Landau-Verwey-Overbeek (DLVO) theory, aggregates depend on interaction forces (van der Waals) and double-layer forces [18].

It is well known that iron and aluminum are the preferred materials to be used as sacrificial anodes. For iron, anode oxidation could lead to either ferrous or ferric ion formation; however, low solubility of $\mathrm{Fe}^{3+}$ ions suggests the release of $\mathrm{Fe}^{2+}$ ions, which are oxidized to ferric ions due to $\mathrm{pH}$ and dissolved oxygen concentration. For aluminum, anode oxidation leads to $\mathrm{Al}^{3+}$ ion formation. In both cases, the subsequent formation of hydroxide compounds induces the presence of monomeric and polymeric amorphous species that trap colloidal particles and promote the soluble pollutant adsorption [14]. Both metals are fine as construction materials for sacrificial electrodes, but for economics, iron has a slight advantage: it is nontoxic, meaning it can be used for drinking water, and it has a lower price. Otherwise, there are many studies that report the effectiveness of aluminum anodes in the EC process for emerging contaminants $[17,19,20]$.

Sand filters are a natural medium that can be used as a filter for wastewater treatment. It displays two roles: the retention of solids and biomass fixation that could be developed on the granular material and the biodegradation of organic, phosphorus, and nitrogenous pollutants [21-23]. For disinfection of wastewater reuse, the turbidity and suspended solids must be reduced to prevent the hiding of pathogens and organisms that hide behind these solids. Currently, the most widely used process to remove residual TSS (total suspended solids) is treated effluent filtration $[24,25]$. The main mechanisms contributing to the removal of suspended solids in sand filters are cast $[22,26]$. This has been identified as the major operating mechanism for the removal of suspended solids during filtration of secondary effluent from processes and biological treatments. Perhaps, other mechanisms, such as interception, impact, and adhesion, are operational, although its effects are minor and mostly marked by the action of casting [27-30].

The purpose of this study is to evaluate the efficiency of integrated electrocoagulation and sand filtration processes as a pretreatment of wastewater from the chocolate manufacturing plants in terms of turbidity, color, and chemical oxygen demand (COD).

\section{Materials and Methods}

2.1. Sampling. The wastewater samples used in this study were collected at the effluent of an industrial chocolate manufacturing plant, preserved, and analyzed according to the standard methods for conventional characterization APHA/AWWA/WEF [31]. The electrocoagulation and filtration were monitored for turbidity, color, and COD, as well as $\mathrm{pH}$ variation. A UV-VIS spectrum of the effluent was done on a PerkinElmer Lambda 25 UV/VIS Spectrophotometer (USA). Color and turbidity were monitored at 465 and $860 \mathrm{~nm}$ wavelengths, respectively, using a Hach $\mathrm{DR} / 4000 \mathrm{U} 110$ spectrometer. COD was analyzed by the 
closed reflux colorimetric method (Method 5220 D; according to APHA) [31].

2.2. Electrocoagulation Process. Electrocoagulation was carried out in a laboratory-scale batch reactor; two rectangular commercial aluminum plates $(99.3 \mathrm{wt} \% \mathrm{Al})$ served as anode and cathode. The anodic and cathodic active surface area was $343 \mathrm{~cm}^{2}$ immersed in wastewater with $0.13721 / \mathrm{cm}$ of the SA/V ratio. A DC power source supplied the system with $0.1 \mathrm{~A}$, corresponding to $0.2915 \mathrm{~mA} / \mathrm{cm}^{2}$ current density which was kept for $120 \mathrm{~min}$. Electrocoagulation was performed without additional electrolyte $(750 \mu \mathrm{S} / \mathrm{cm}$ conductivity in wastewater). The electrodes were connected to a digital DC power supply (GW Instek GPR-1820HD, $0-18 \mathrm{~V} ; 0-20 \mathrm{~A}$, China). Twenty-five $\mathrm{mL}$ of sample was taken every 30 min during the $2 \mathrm{~h}$ electrocoagulation process. The efficiency of EC was evaluated by measuring the turbidity, color, and chemical oxygen demand (COD) [32].

2.3. Filtration Process. Two horizontal conventional downflow filters (sand filter A and sand filter B) installed in parallel were used for the filtration process; the filter media of each filter included two beds composed of gravel $1 / 4 \times 1 / 8$ $(24 \mathrm{~cm})$ and gravel $1 / 8 \times 1 / 16(51 \mathrm{~cm})$, each filter measuring $168 \mathrm{~cm}$ in length and $15 \mathrm{~cm}$ in diameter. The effective size for each filter was $0.71 \mathrm{~mm}$. In the bottom of each filter, gravel particles $(3 / 4 \times 1 / 2)$ were placed to support upper layers. The filtration process was carried out after completing the electrocoagulation process, as shown in Figure 1. At the filter outlet, turbidity and dissolved oxygen (DO) were monitored. Filtration experiments were performed without recirculation.

The removal efficiency was calculated using

$$
Y(\%)=\frac{\left(y_{0}-y\right)}{y_{0}},
$$

where $Y$ is the removal efficiency of turbidity/color/COD and $y_{0}$ and $y$ correspond to the initial and final values of a determined parameter, respectively.

\section{Results and Discussion}

Table 1 presents the initial physicochemical parameters of wastewater from the chocolate manufacturing process. The wastewater contained pollutants, which were reflected in high levels of COD, due to ingredients used in chocolate manufacturing such as cocoa bean, chocolate liquor obtained from the broken beans that are ground, cocoa butter obtained from the broken-down cell walls, sugar, and emulsifiers in conjunction with the waste from the processes of cleaning, fermentation, drying, roasting, grinding, pressing, spraying, and mixing $[1,33]$. The color and turbidity values obtained are harmful to aquatic life, obstructing light penetration in the water, inhibiting thus the photosynthesis-based biological processes [31]. The $\mathrm{pH}$ was about 7.5, which was basically a neutral $\mathrm{pH}$ environment. Contaminants all achieved maximum removal in this $\mathrm{pH}$ condition [30]. Therefore, the following tests were performed using the raw water without $\mathrm{pH}$ adjustment, in agreement with previous studies, where the wastewater was used directly for electrocoagulation experiments [34].

3.1. Electrocoagulation Process Efficiency. After $120 \mathrm{~min}$ of treatment, the reductions in turbidity, color, and COD for the electrocoagulation process were $87.8 \pm 0.6 \%, 98.2$ $\pm 0.2 \%$, and $39.02 \pm 2.2 \%$, respectively (Figure 2 ). The experiments were repeated three times to verify the reproducibility of the results; in any experiment, the values of the coefficient of variation were no higher than $5 \%$, indicating that recollected data have an statistical acceptance criteria. Zhao et al. carried out EC experiments as a pretreatment applied to wastewater containing oil, grease, and other inorganic contaminants; their results showed a removal of $93.8 \%$ in turbidity under the following conditions: $5.56 \mathrm{~mA} / \mathrm{cm}^{2}$ of current density and $30 \mathrm{~min}$ of reaction time [34]. Regarding color removal, Ricordel and Djelal obtained a removal of $80 \%$ after EC treatment of landfill leachate, although not the same substrate; this had high levels of organic matter, refractory compounds, inorganic contaminants, and color [32]. In addition, an efficiency greater than $32 \%$ was obtained for Farhadi et al. by comparing electrocoagulation $\left(1.83 \mathrm{~mA} / \mathrm{cm}^{2}\right.$ of current density and $30 \mathrm{~min}$ of time reaction) and an advanced oxidation process during pharmaceutical wastewater treatment [35]. The removal of turbidity, color, and COD is attributed to sweep flocculation [34]. In the EC process, coagulating ions are produced in situ, involving three successive stages: (i) formation of coagulants by electrolytic oxidation of the sacrificial electrode of $\mathrm{Al}$; (ii) destabilization of the contaminants, particulate suspension, and breaking of emulsions; and (iii) aggregation of the destabilized phases to form flocs. $\mathrm{Al}$ gets dissolved from the anode, generating corresponding metal ions that almost immediately hydrolyze to polymeric aluminum oxyhydroxides $[4,36]$. These polymeric oxyhydroxides are excellent coagulating agents. When aluminum electrodes in the EC process are used as anode and cathode, the main reactions at the anode are as follows:

$$
\mathrm{Al} \rightarrow \mathrm{Al}^{3+}+3 e^{-}
$$

Also, oxygen evolution can compete with aluminum dissolution at the anode via

$$
2 \mathrm{H}_{2} \mathrm{O} \rightarrow \mathrm{O}_{2(\mathrm{~g})}+4 \mathrm{H}^{+}+4 e^{-}
$$

At the cathode, hydrogen evolution takes place via the following reaction, assisting in the floatation of the flocculated particles out of the water:

$$
3 \mathrm{H}_{2} \mathrm{O}+3 e^{-} \rightarrow \frac{3}{2} \mathrm{H}_{2}+3 \mathrm{OH}^{-}
$$

At high $\mathrm{pH}$ values, $\mathrm{OH}^{-}$generated at the cathode during hydrogen evolution may attack the cathode by the following reaction $[18,37]$ :

$$
2 \mathrm{Al}+6 \mathrm{H}_{2} \mathrm{O}+2 \mathrm{OH}^{-} \rightarrow 2 \mathrm{Al}(\mathrm{OH})_{4}{ }^{-}+3 \mathrm{H}_{2(\mathrm{~g})}
$$

$\mathrm{Al}^{3+}$ and hydroxyl ions are generated by electrode reactions as shown in (2), (4), and (5) to form various monomeric-polymeric species transformed initially into 


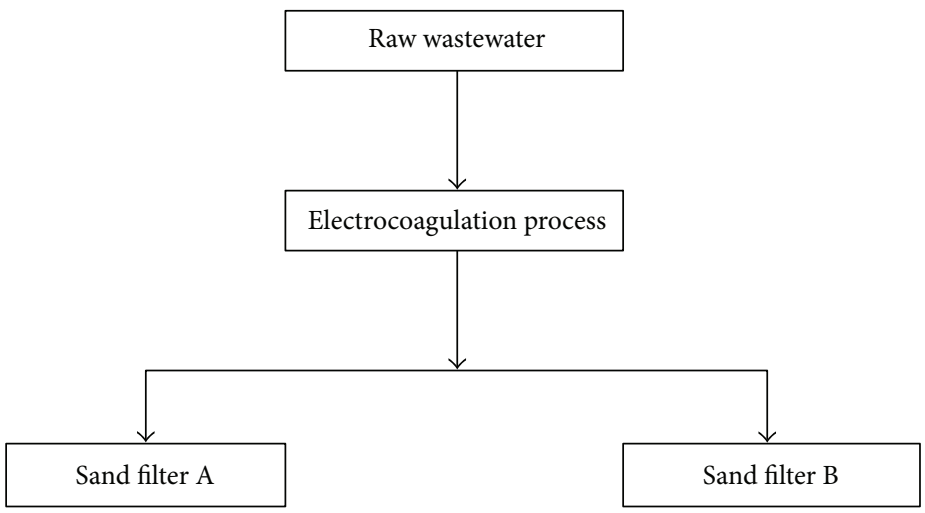

Figure 1: Flow chart used in this study.

TABLE 1: Initial and final physicochemical parameters from treated wastewater.

\begin{tabular}{|c|c|c|c|c|c|c|}
\hline \multicolumn{3}{|c|}{ Raw wastewater } & \multicolumn{3}{|c|}{ Treated wastewater } & \multirow[b]{2}{*}{$\%$ Removal in the integrated process } \\
\hline Parameter & Value & Units & Parameter & Value & Units & \\
\hline COD & $3608 \pm 250$ & $\mathrm{mg} / \mathrm{L}$ & COD & $2200 \pm 11$ & $\mathrm{mg} / \mathrm{L}$ & $39.02 \pm 2.2$ \\
\hline Color & $5952 \pm 76$ & Pt-Co & Color & $101 \pm 17$ & Pt-Co & $98.2 \pm 0.26$ \\
\hline Turbidity & $1648 \pm 49$ & $\mathrm{mg} / \mathrm{L}$ & Turbidity & $64 \pm 5$ & $\mathrm{mg} / \mathrm{L}$ & $96.1 \pm 0.2$ \\
\hline $\mathrm{pH}$ & $7.4 \pm 0.06$ & & $\mathrm{pH}$ & $9.11 \pm 0.03$ & & \\
\hline \multirow[t]{2}{*}{ Conductivity } & $750 \pm 28$ & $\mu \mathrm{S} / \mathrm{cm}$ & Conductivity & $520 \pm 9$ & $\mu \mathrm{S} / \mathrm{cm}$ & \\
\hline & & & Energy consumption & 0.32 & $\mathrm{kWh} / \mathrm{m}^{3}$ & \\
\hline
\end{tabular}

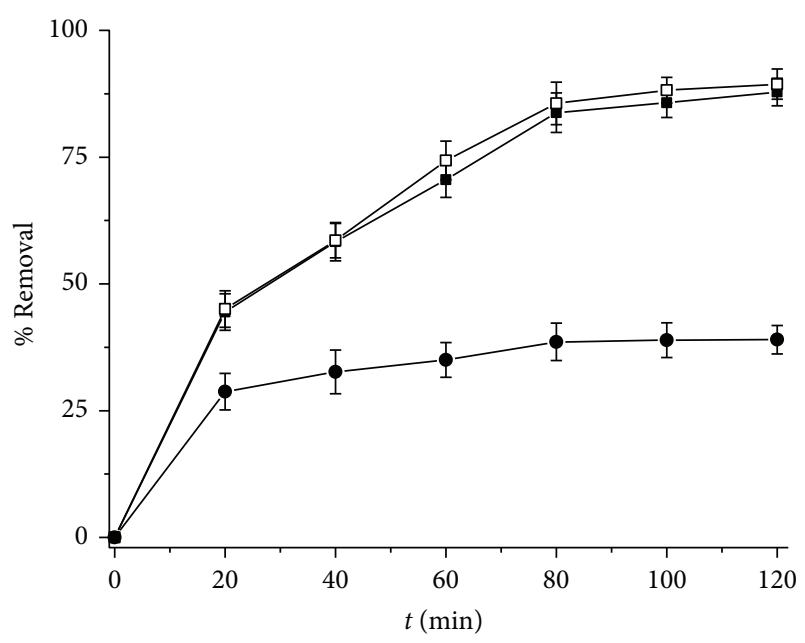

Figure 2: Contaminant removal efficiency in wastewater treated after the electrocoagulation process at a current density of $0.2915 \mathrm{~mA} / \mathrm{cm}^{2}$ : turbidity $(\boldsymbol{\square})$, color $(\square)$, and COD $(\bullet)$.

$\mathrm{Al}(\mathrm{OH})_{3(\mathrm{~s})}$ and finally polymerized to $\mathrm{Al}_{n}(\mathrm{OH})_{3 n}((6)$ and (7)) in the solution [32, 37-39]:

$$
\begin{gathered}
\mathrm{Al}^{3+}+3 \mathrm{H}_{2} \mathrm{O} \rightarrow \mathrm{Al}(\mathrm{OH})_{3(\mathrm{~s})}+3 \mathrm{H}^{+} \\
n \mathrm{Al}(\mathrm{OH})_{3} \rightarrow \mathrm{Al}_{n}(\mathrm{OH})_{3 n}
\end{gathered}
$$

Since the electrocoagulation process is based on removal of the colloidal/particulate COD fraction of wastewater, the

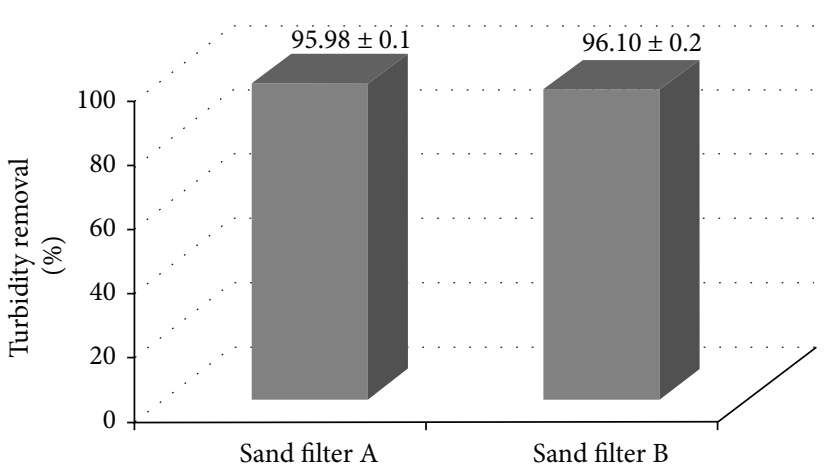

FIGURE 3: Turbidity removal efficiency in treated wastewater.

low efficiency of COD obtained in this process is attributed to the soluble COD fraction in raw wastewater [40].

3.2. Filtration Process Efficiency. As shown in Figure 3, the turbidity after the filtration processes was lower than the initial turbidity, which was $1648 \pm 49$ FAU in raw wastewater; turbidity removals (\%) reached were $95.98 \pm 0.1$ and 96.10 \pm 0.2 for filters $\mathrm{A}$ and $\mathrm{B}$, respectively. The turbidity removal was due to the working-in stage (characterized by a rapid decrease in effluent turbidity) and working stage (the effective stage of filtration giving satisfactory effluent quality) [30]. Similar results were obtained by Ramadan, whose results reached $98.05 \%$ removal of total suspended solids (TSS) using nonconventional sand filters $\left(\mathrm{TiO}_{2}\right.$ was added 


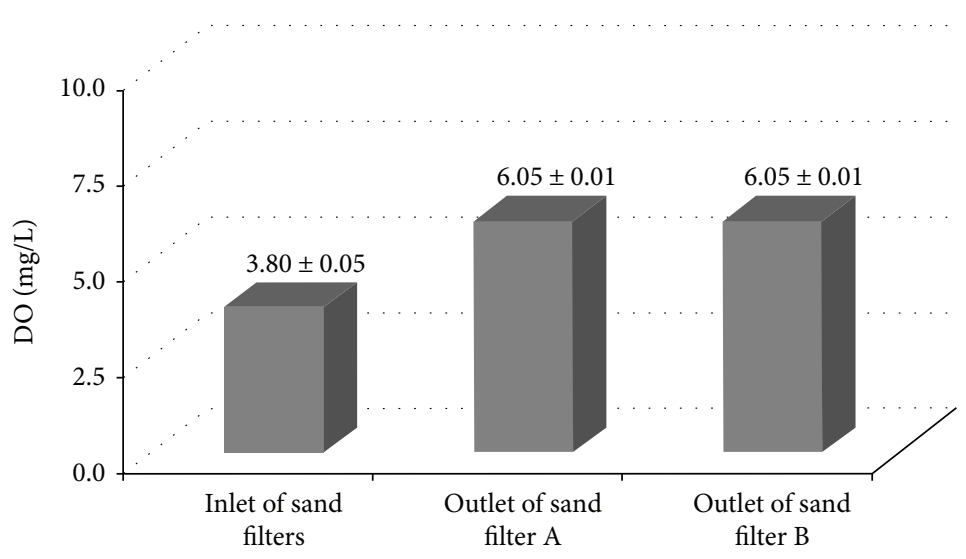

FIGURE 4: Dissolved oxygen in filtration process.

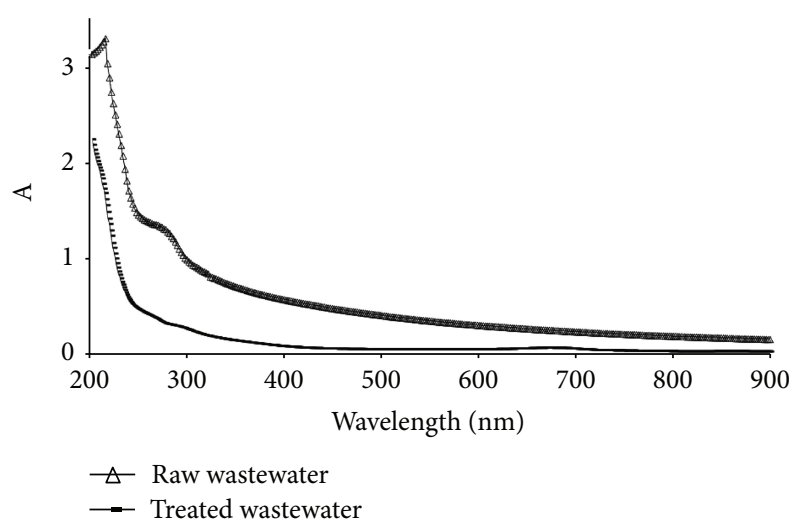

FIGURE 5: UV/VIS spectrum of the raw wastewater and treated wastewater in the electrocoagulation-filtration process at a current density of $0.2915 \mathrm{~mA} / \mathrm{cm}^{2}$.

to the sand filter) in reducing pollutants from wastewater [41]. Finally, Achak et al. obtained results of $90 \%$ turbidity removal from olive mill wastewater generated by the olive oil extraction process [42]. After electrocoagulation, sand filtration could remove flocs by attaching them to the sand grain to improve the removal of turbidity from $87.80 \%$ in the EC process to $99.10 \%$ after filtration obtained an increase by $11.40 \%$; a statistical test was performed, determining that a statistically significant difference exists between both processes $(p$ value $=0.018)$.

The concentration of dissolved oxygen in the inlet of each sand filter increased from $3.8 \pm 0.05 \mathrm{mg} / \mathrm{L}$ to $6.05 \pm 0.01 \mathrm{mg} / \mathrm{L}$ after the filtration process during the $120 \mathrm{~min}$ experiment (Figure 4). The oxygenation of sand filters is due to the gaseous exchange between the atmosphere and the interstices of sand in the surface of the filter. These results are good because adequate dissolved oxygen is needed for good water quality and is necessary for all forms of elemental life.

3.3. UV/VIS Spectra of the Treated Wastewater. The spectrum for the raw wastewater $(\Delta)$ presented a baseline with one absorbance peak at $290 \mathrm{~nm}$, which was associated with the contaminants in this matrix $(3608 \pm 250 \mathrm{mg} / \mathrm{L}$
COD). For $120 \mathrm{~min}$ of reaction, treated wastewater by an electrocoagulation-filtration-coupled process (a) showed the highest efficiency in removing turbidity, color, and COD together with a decrease in the baseline and in the absorbance peaks, as shown in Figure 5. The removal of contaminants (initial DQO $=3608 \pm 250 \mathrm{mg} / \mathrm{L}$ and final D $\mathrm{QO}=2200 \pm 11 \mathrm{mg} / \mathrm{L}$ ) was indicated by the decrease in the absorption band at $290 \mathrm{~nm}$ and baseline [43]

\section{Conclusions}

Removal of contaminants was efficient by integrating electrocoagulation and filtration processes as a pretreatment of wastewater from chocolate manufacturing plants, which was reflected in increased removal percentages of turbidity and color and an increase in dissolved oxygen after the integrated filtration processes.

UV/VIS spectra intensity decreased between raw and treated wastewater, indicating the removal of pollutants in the integrated process.

The EC process removed the colloidal/particulate COD fraction in raw wastewater; however, the remaining COD due to the soluble COD fraction was not removed in the integrated process.

\section{Disclosure}

This work was presented as a poster with the title "Wastewater Treatment of Chocolate Manufacture Industry through an Integrated Process of Electrocoagulation and Filtration" at Electrochemical Treatments for Organic Pollutant Degradation in Water and Soils, 2014, ECS and SMEQ Joint International Meeting.

\section{Conflicts of Interest}

The authors declare that there is no conflict of interest regarding the publication of this paper. 


\section{Acknowledgments}

The authors wish to acknowledge the support given by CONACYT and the Tecnológico Nacional de México for the development of this research through Project TecNM 5652.15-P.

\section{References}

[1] M. El-kalyoubi, M. F. Khallaf, A. Abdelrashid, and E. M. Mostafa, "Quality characteristics of chocolate - containing some fat replacer," Annals of Agricultural Science, vol. 56, no. 2, pp. 89-96, 2011.

[2] P. B. Botelho, M. Galasso, V. Dias et al., "Oxidative stability of functional phytosterol-enriched dark chocolate," LWT - Food Science and Technology, vol. 55, no. 2, pp. 444-451, 2014.

[3] M. V. Copetti, B. T. Iamanaka, M. A. Nester, P. Efraim, and M. H. Taniwaki, "Occurrence of ochratoxin A in cocoa byproducts and determination of its reduction during chocolate manufacture," Food Chemistry, vol. 136, no. 1, pp. 100-104, 2013.

[4] E. Gengec, M. Kobya, E. Demirbas, A. Akyol, and K. Oktor, "Optimization of baker's yeast wastewater using response surface methodology by electrocoagulation," Desalination, vol. 286, pp. 200-209, 2012.

[5] Y. J. Chan, M. F. Chong, C. L. Law, and D. G. Hassell, "A review on anaerobic-aerobic treatment of industrial and municipal wastewater," Chemical Engineering Journal, vol. 155, no. 1-2, pp. 1-18, 2009.

[6] M. Luan, G. Jing, Y. Piao, D. Liu, and L. Jin, "Treatment of refractory organic pollutants in industrial wastewater by wet air oxidation," Arabian Journal of Chemistry, vol. 10, no. 1, pp. S769-S776, 2017.

[7] M. S. Nawaz and M. Ahsan, "Comparison of physico-chemical, advanced oxidation and biological techniques for the textile wastewater treatment," Alexandria Engineering Journal, vol. 53, no. 3, pp. 717-722, 2014.

[8] S. Renou, J. G. Givaudan, S. Poulain, F. Dirassouyan, and P. Moulin, "Landfill leachate treatment: review and opportunity," Journal of Hazardous Materials, vol. 150, no. 3, pp. 468-493, 2008.

[9] D. Shahidi, R. Roy, and A. Azzouz, "Advances in catalytic oxidation of organic pollutants - prospects for thorough mineralization by natural clay catalysts," Applied Catalysis B: Environmental, vol. 174-175, pp. 277-292, 2015.

[10] G. Boczkaj and A. Fernandes, "Wastewater treatment by means of advanced oxidation processes at basic $\mathrm{pH}$ conditions: a review," Chemical Engineering Journal, vol. 320, pp. 608-633, 2017.

[11] L. Bilińska, M. Gmurek, and S. Ledakowicz, "Comparison between industrial and simulated textile wastewater treatment by AOPs - biodegradability, toxicity and cost assessment," Chemical Engineering Journal, vol. 306, pp. 550-559, 2016.

[12] W. Baran, E. Adamek, M. Jajko, and A. Sobczak, "Removal of veterinary antibiotics from wastewater by electrocoagulation," Chemosphere, vol. 194, pp. 381-389, 2018.

[13] D. T. Moussa, M. H. El-Naas, M. Nasser, and M. J. Al-Marri, "A comprehensive review of electrocoagulation for water treatment: potentials and challenges," Journal of Environmental Management, vol. 186, no. 1, pp. 24-41, 2017.
[14] J. N. Hakizimana, B. Gourich, M. Chafi et al., "Electrocoagulation process in water treatment: a review of electrocoagulation modeling approaches," Desalination, vol. 404, pp. 1-21, 2017.

[15] Y. A. Ouaissa, M. Chabani, A. Amrane, and A. Bensmaili, "Removal of tetracycline by electrocoagulation: kinetic and isotherm modeling through adsorption," Journal of Environmental Chemical Engineering, vol. 2, no. 1, pp. 177-184, 2014.

[16] D. Valero, J. M. Ortiz, V. García, E. Expósito, V. Montiel, and A. Aldaz, "Electrocoagulation of wastewater from almond industry," Chemosphere, vol. 84, no. 9, pp. 1290-1295, 2011.

[17] E. Nariyan, A. Aghababaei, and M. Sillanpää, "Removal of pharmaceutical from water with an electrocoagulation process; effect of various parameters and studies of isotherm and kinetic," Separation and Purification Technology, vol. 188, pp. 266-281, 2017.

[18] S. Garcia-Segura, M. M. S. G. Eiband, J. V. de Melo, and C. A. Martínez-Huitle, "Electrocoagulation and advanced electrocoagulation processes: a general review about the fundamentals, emerging applications and its association with other technologies," Journal of Electroanalytical Chemistry, vol. 801, pp. 267-299, 2017.

[19] S. Ahmadzadeh, A. Asadipour, M. Pournamdari, B. Behnam, H. Reza Rahimi, and M. Dolatabadi, "Removal of ciprofloxacin from hospital wastewater using electrocoagulation technique by aluminum electrode: optimization and modelling through response surface methodology," Process Safety and Environmental Protection, vol. 109, pp. 538-547, 2017.

[20] M. Çırak, "High-temperature electrocoagulation of colloidal calcareo-argillaceous suspension," Powder Technology, vol. 328, no. 1, pp. 13-25, 2018.

[21] S. E. Keithley and M. J. Kirisits, “An improved protocol for extracting extracellular polymeric substances from granular filter media," Water Research, vol. 129, pp. 419-427, 2018.

[22] Y. Gherairi, A. Amrane, Y. Touil, M. Hadj Mahammed, F. Gherairi, and I. Baameur, "A comparative study of the addition effect of activated carbon obtained from date stones on the biological filtration efficiency using sand dune bed," Energy Procedia, vol. 36, pp. 1175-1183, 2013.

[23] P. Laaksonen, A. Sinkkonen, G. Zaitsev, E. Mäkinen, T. Grönroos, and M. Romantschuk, "Treatment of municipal wastewater in full-scale on-site sand filter reduces BOD efficiently but does not reach requirements for nitrogen and phosphorus removal," Environmental Science and Pollution Research, vol. 24, no. 12, pp. 11446-11458, 2017.

[24] S. Mtavangu, A. M. Rugaika, A. Hilonga, and K. N. Njau, "Performance of constructed wetland integrated with sand filters for treating high turbid water for drinking," Water Practice and Technology, vol. 12, no. 1, pp. 25-42, 2017.

[25] R. Bauer, H. Dizer, I. Graeber, K.-H. Rosenwinkel, and J. M. López-Pila, "Removal of bacterial fecal indicators, coliphages and enteric adenoviruses from waters with high fecal pollution by slow sand filtration," Water Research, vol. 45, no. 2, pp. 439-452, 2011.

[26] M. De Sanctis, G. Del Moro, S. Chimienti, P. Ritelli, C. Levantesi, and C. Di Iaconi, "Removal of pollutants and pathogens by a simplified treatment scheme for municipal wastewater reuse in agriculture," Science of the Total Environment, vol. 580, pp. 17-25, 2017.

[27] C. N. Mushila, G. M. Ochieng, F. A. O. Otieno, S. M. Shitote, and C. W. Sitters, "Hydraulic design to optimize the treatment capacity of multi-stage filtration units," Physics and Chemistry of the Earth, Parts A/B/C, vol. 92, pp. 85-91, 2016. 
[28] E. Bar-Zeev, N. Belkin, B. Liberman, T. Berman, and I. Berman-Frank, "Rapid sand filtration pretreatment for SWRO: microbial maturation dynamics and filtration efficiency of organic matter," Desalination, vol. 286, pp. 120130, 2012.

[29] M. Elbana, F. Ramírez de Cartagena, and J. Puig-Bargués, "Effectiveness of sand media filters for removing turbidity and recovering dissolved oxygen from a reclaimed effluent used for micro-irrigation," Agricultural Water Management, vol. 111, pp. 27-33, 2012.

[30] A. Y. Zahrim and N. Hilal, "Treatment of highly concentrated dye solution by coagulation/flocculation-sand filtration and nanofiltration," Water Resources and Industry, vol. 3, pp. 2334, 2013.

[31] APHA, AWWA, WEF, Standard Methods for Examination of Water and Wastewater, American Public Health Association, Washington, DC, USA, 22nd edition, 2012.

[32] C. Ricordel and H. Djelal, "Treatment of landfill leachate with high proportion of refractory materials by electrocoagulation: system performances and sludge settling characteristics," Journal of Environmental Chemical Engineering, vol. 2, no. 3, pp. 1551-1557, 2014.

[33] M. Gültekin-Özgüven, İ. Berktaş, and B. Özçelik, "Influence of processing conditions on procyanidin profiles and antioxidant capacity of chocolates: optimization of dark chocolate manufacturing by response surface methodology," LWT - Food Science and Technology, vol. 66, pp. 252-259, 2016.

[34] S. Zhao, G. Huang, G. Cheng, Y. Wang, and H. Fu, "Hardness, $\mathrm{COD}$ and turbidity removals from produced water by electrocoagulation pretreatment prior to reverse osmosis membranes," Desalination, vol. 344, pp. 454-462, 2014.

[35] S. Farhadi, B. Aminzadeh, A. Torabian, V. Khatibikamal, and M. Alizadeh Fard, "Comparison of COD removal from pharmaceutical wastewater by electrocoagulation, photoelectrocoagulation, peroxi-electrocoagulation and peroxiphotoelectrocoagulation processes," Journal of Hazardous Materials, vol. 219-220, pp. 35-42, 2012.

[36] M. Kobya, M. S. Oncel, E. Demirbas, E. Şık, A. Akyol, and M. Ince, "The application of electrocoagulation process for treatment of the red mud dam wastewater from Bayer's process," Journal of Environmental Chemical Engineering, vol. 2, no. 4, pp. 2211-2220, 2014

[37] S. Tchamango, C. P. Nanseu-Njiki, E. Ngameni, D. Hadjiev, and A. Darchen, "Treatment of dairy effluents by electrocoagulation using aluminium electrodes," Science of The Total Environment, vol. 408, no. 4, pp. 947-952, 2010.

[38] M. Mechelhoff, G. H. Kelsall, and N. J. D. Graham, "Electrochemical behaviour of aluminium in electrocoagulation processes," Chemical Engineering Science, vol. 95, pp. 301-312, 2013.

[39] M. A. Sandoval, R. Fuentes, J. L. Nava, and I. Rodríguez, "Fluoride removal from drinking water by electrocoagulation in a continuous filter press reactor coupled to a flocculator and clarifier," Separation and Purification Technology, vol. 134, pp. 163-170, 2014.

[40] Z. Hu, K. Chandran, B. F. Smets, and D. Grasso, "Evaluation of a rapid physical-chemical method for the determination of extant soluble COD," Water Research, vol. 36, no. 3, pp. 617-624, 2002.

[41] M. Ramadan, "Efficiency of new Miswak, titanium dioxide and sand filters in reducing pollutants from wastewater," Beni-Suef
University Journal of Basic and Applied Sciences, vol. 4, no. 1, pp. 47-51, 2015.

[42] M. Achak, L. Mandi, and N. Ouazzani, "Removal of organic pollutants and nutrients from olive mill wastewater by a sand filter," Journal of Environmental Management, vol. 90, no. 8, pp. 2771-2779, 2009.

[43] M. A. García-Morales, G. Roa-Morales, C. Barrera-Díaz, V. Martínez Miranda, P. Balderas Hernández, and T. B. Pavón Silva, "Integrated advanced oxidation process (ozonation) and electrocoagulation treatments for dye removal in denim effluents," International Journal of Electrochemical Science, vol. 8, pp. 8752-8763, 2013. 

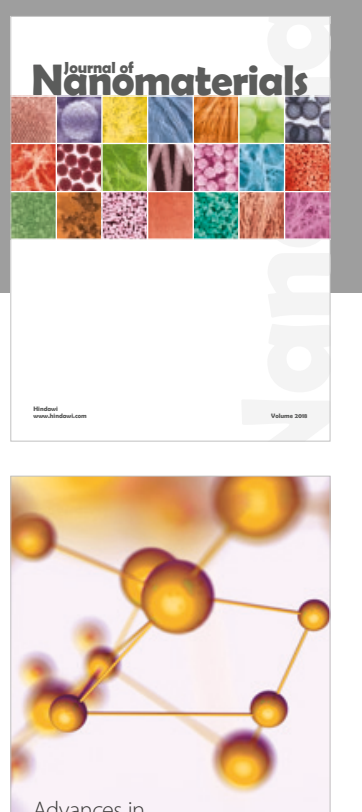

Physical Chemistry
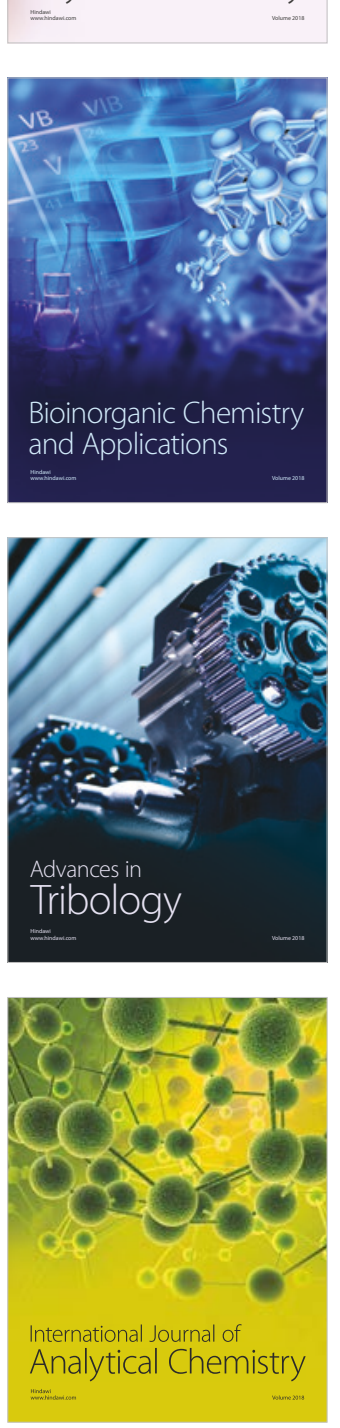

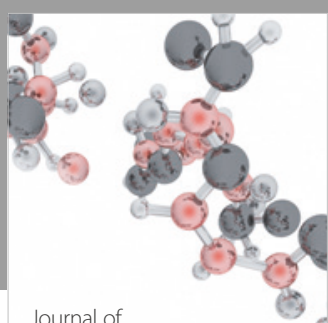

Analytical Methods

in Chemistry

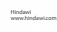

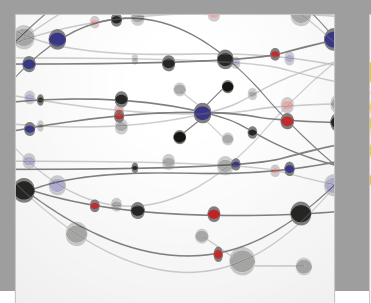

The Scientific World Journal

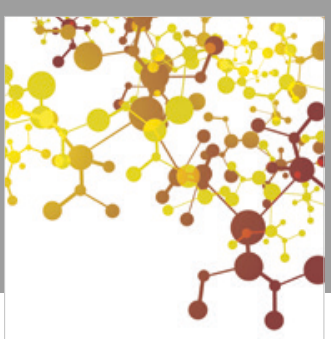

Journal of

Applied Chemistry
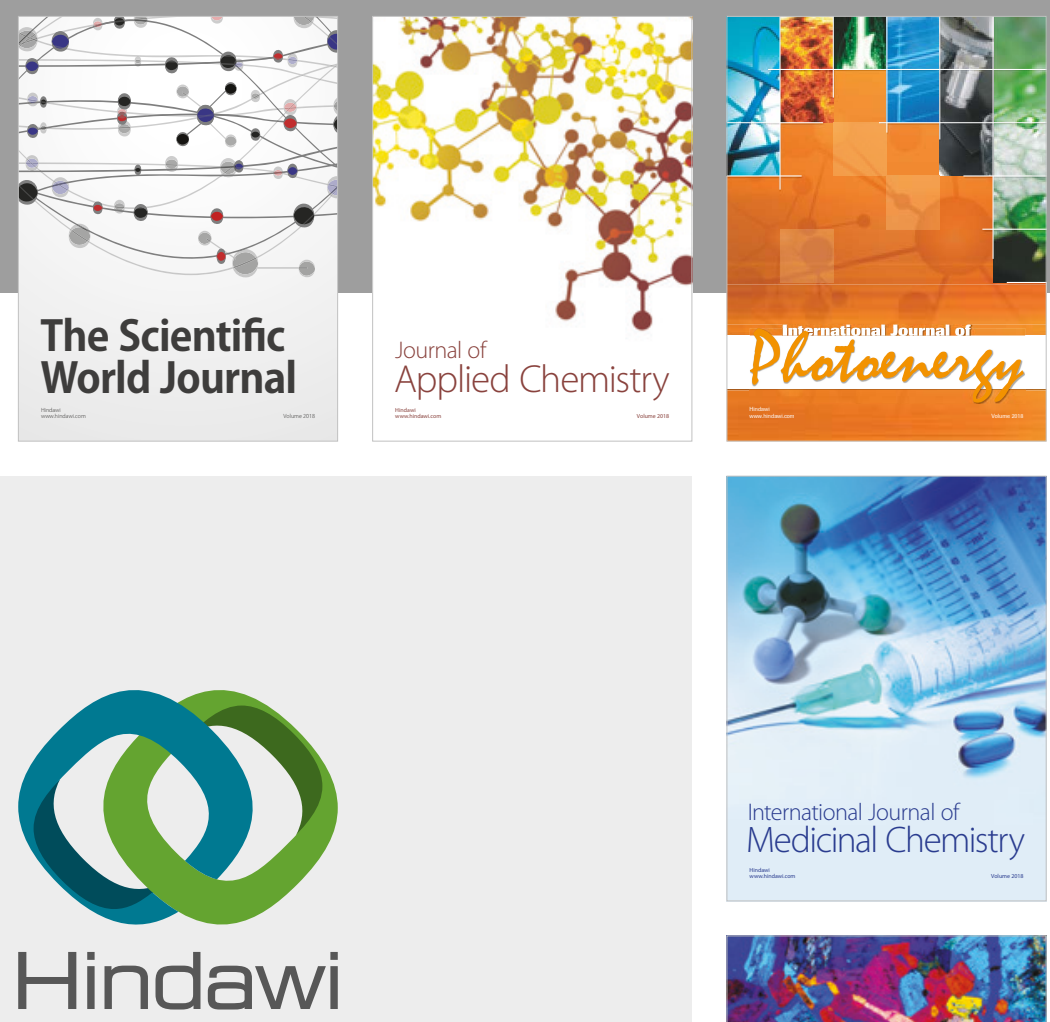

Submit your manuscripts at

www.hindawi.com
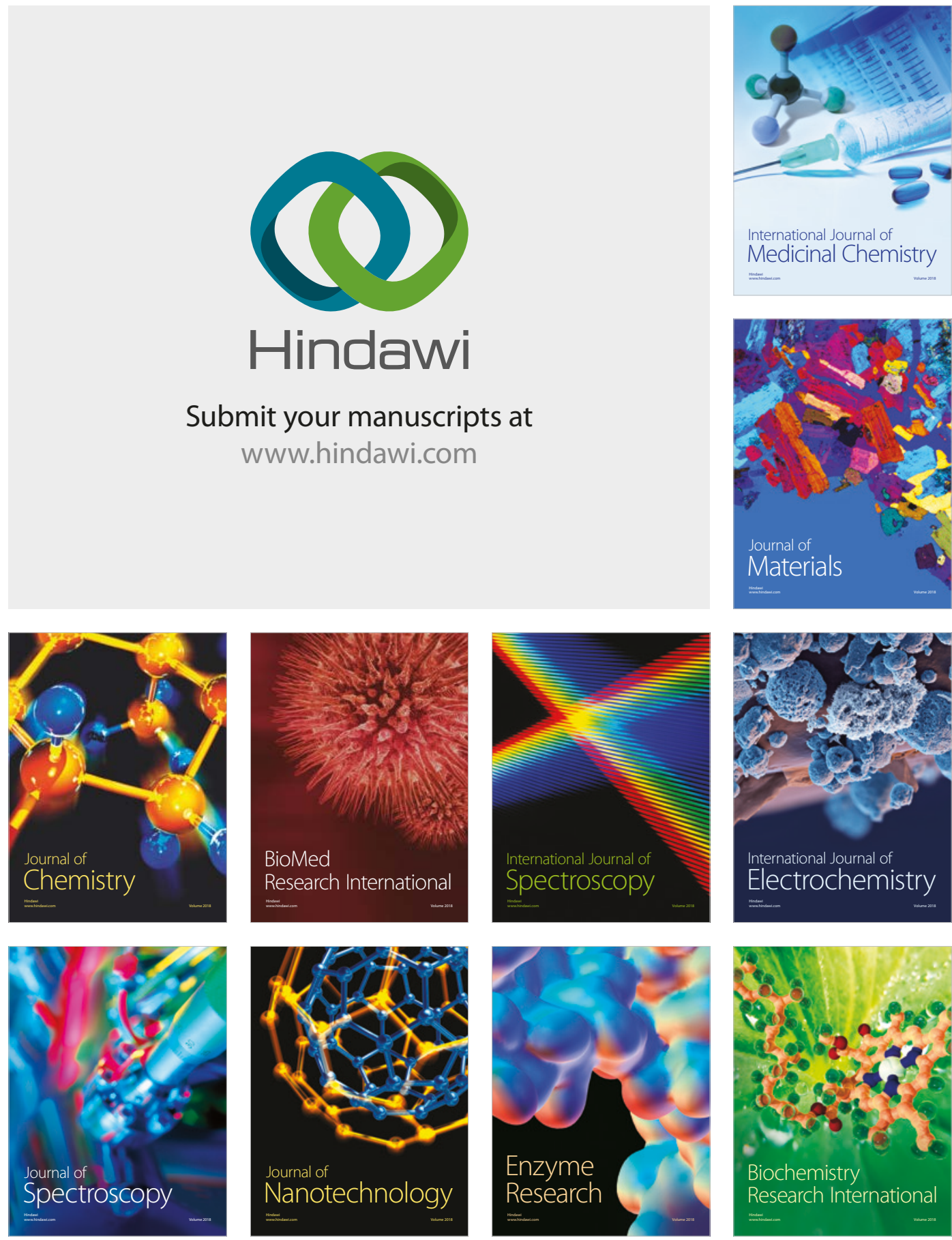
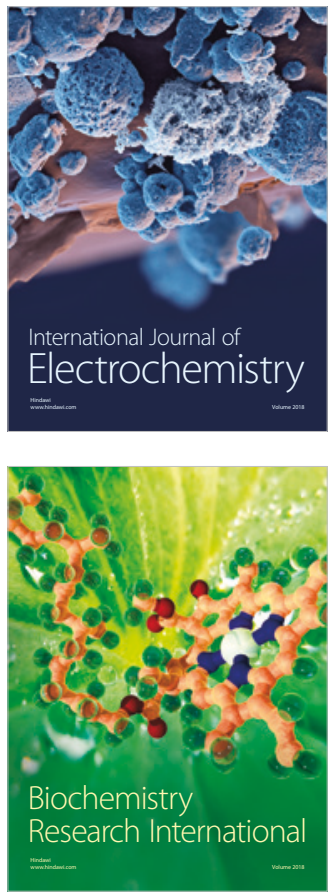